\title{
The Influence of The Motivation, Leadership and Social Networking for the Formation of Social Entrepreneurship
}

\author{
Trianom Suryandharu ${ }^{1, \mathrm{a}, \#}$, Anwar Sanusi ${ }^{2, \mathrm{~b}} \&$ Harsono $^{2, \mathrm{c}}$ \\ ${ }^{1}$ Ma Chung University, Villa Puncak Tidar, Malang, 65146, Indonesia \\ ${ }^{2}$ Merdeka University, Jl. Terusan Dieng No. 62-64, Malang, 65146, Indonesia

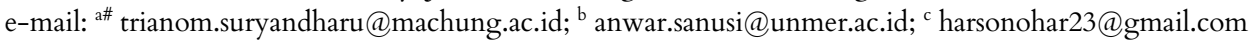 \\ \#Corresponding Author \\ Whatsapp Number $\{+62-8125203816\}$
}

\section{ARTICLE HISTORY}

Received: 23 March 2019

Revised: 25 April 2019

Accepted: 20 June 2019

Copyright $\odot 2019$ Authors \& Published by IIES Independent. This is an open-access article distributed under the terms of the CC-BY-SA License.

\section{ABSTRACT}

When the Indonesian people experienced the economic crisis of 1997-1998, it resulted in farmers having difficulty accessing the products used as their production facilities. They solved the problem by pioneering social entrepreneurship. This study explores motivation, leadership and social networks as independent variables in the process of pioneering social entrepreneurship conducted by Sumber Makmur I Farmers Community in, Lawang, Malang, East Java. Then identified the three variables to determine the dominant variable influencing the pioneering of social entrepreneurship. The method used in this study is quantitative. The population is 40 farmers who plant rice with organic methods that are collected by census. The results showed that motivation, leadership and social networks had influence on the efforts of pioneering social entrepreneurship conducted by the Sumber Makmur I Farmers Community. The leadership variable was the dominant variable.

Keywords: Social Entrepreneurship; Motivation; Leadership; Social Networking

How to Cite: Suryandharu, T., Sanusi, A., \& Harsono (2019). The Influence of The Motivation, Leadership and Social Networking for the Formation of Social Entrepreneurship. International Journal of Advances in Social and Economics, 1(1), 6-15.

\section{Introduction}

The Indonesian nation experienced a monetary crisis which continued into the economic crisis in 19971998. In the period of January- July 1997 the exchange rate of the rupiah against the US dollar was IDR 2,400 per US dollar. In January 1998, it increased to IDR 10,375 per US dollar and in June 1998, it was IDR 14,900 per US dollar (Siti Romida Harahap, 2013: 320). The price of goods increased, including the price of commodities for agricultural production. The members of the Sumber Makmur I Farmers Group in Sumber Ngepoh village, Lawang, Malang Regency, East Java, Indonesia had difficulty buying the required products, because they were expensive, also rare in the market.

The commodity of farmers' needs is the result of the New Order government's policy of implementing the Green Revolution in 1969. According to Sutrisno (2002: 10) the implementation of the Green Revolution policy has changed the attitude of farmers who forget local knowledge about agricultural skills and make farmers dependent on market mechanisms, including causing damage to land and the use of chemical pesticides that damage the balance of environmental ecosystems (Sutanto 2002). The economic crisis had resulted in increasingly expensive and unreachable prices for agricultural production facilities, so farmers are aware that they are experiencing dependence on inventory on the market. It is the momentum that drives them to apply organic farming as their predecessors have done by building a business entity to solve the problem at hand.

Through existing farmer group institutions, these farmers build an entrepreneurial unit to answer economic issues as well as the social problems they face. In the academic study, the scope of social 
entrepreneurship does not have a long historical root (Weerawardena, 2006), so that there is no agreement on its standard definition (Mair, 2003). In terms of etymology, according to Barringer and Ireland (2013) the word entrepreneurship is derived from french 'entre' which means between and 'prendere' which means to take. In the original language, the word is used to describe the person who 'takes risks' between the buyer and seller or the person who actively undertakes something.

An important formulation of entrepreneurship in the context of economics is found in Richard Cantillon's work entitled Essai sur la nature du commerce en general (Robert F. Hebert and Albert N. (2006: p. 274; Hamilton, RT, and, Harper, DA, 1994, p. 3-4). According to Cantilon, entrepreneurs are those who buy a number of commodities and resell them to wholesalers, small traders or retailers who benefit because of their courage to take risks on uncertain situations (Robert F. Hebert and Albert N. (2006 : p. 274) For J. Schumpeter (1883-1950) a person is called an entrepreneur if he produces a new combination of results from the impulse of creativity resulting in renewal (innovation) involving the introduction of new products or quality, new methods or processes, new markets, new supply sources or new forms of industrial organization (Schumpeter, 1934).

Peter Drucker (1985) emphasizes the notion of entrepreneurship in an ability to find and maximize opportunities. Opportunities that exist require more than luck or intuition. Opportunities require innovation and are systematically organized to be exploited. According to Thomas W. Zimmere and Norman M. Scarborough and Doug Wilson (2008: 4) entrepreneurs are someone who creates a new business by taking risks and uncertainties in order to achieve profits and growth by identifying significant opportunities and combining the resources needed so that the source -The resource can be capitalized.

Bank (1972) introduced the term social entrepreneurship as a person who uses his entrepreneurial abilities to solve social problems. Social entrepreneurship became an alternative solution when post-World War II with the widespread negative impact of industrialization: the high level of urbanization, along with problems with low attention to health, sanitation, illiteracy, malnutrition, to poverty and social inequality according to Bornstein (2010) became the background behind the emergence of social entrepreneurship. In addition to social issues, according to Singh (2016: 3) the application of a democratic system also affects the emergence of social entrepreneurship. Social problems triggered by the inability of the sector/first party (public/government) and second parties (private / industry) encourage third parties (civil-society/society) to be able to answer the problems they face themselves. The crisis has prompted the government and the private sector to reduce their assistance or subsidies to marginalized groups, so that groups or charitable institutions (philanthropy) find a way out so that their missions are sustainable by not relying on donors from both the private sector and the government.

Some authors define social entrepreneurship as an effort to create social value resulting from collaboration or collaboration with people/communities and organizations from civil society involved in social innovations applied in economic activities (Hulgard: 2010, Nicholls: 2006), creation value as an innovative social impact in the nonprofit sector, business and government (Austin, 2006) thus increasing social wealth (Zahra, 2009). Dees (1998) emphasizes four points that are the focus of the formulation of social entrepreneurship, namely: (1) Adopting social missions to create and maintain continuity (sustainability) of social values; (2) Pursue new opportunities to achieve the social mission; (3) Engaging in the process of continuous innovation, adaptation and learning; (4) Having the courage to take risks in acting even with limited resources; (5) Demonstrate accountability to the parties served as beneficiaries.

Light (2006: 50) provides a formula that social entrepreneurship is an individual, group, network, organization or alliance of organizations that seeks a large and fundamental change on an ongoing basis through ideas that break the deadlock regarding what and how government, profit institutions (business) or non-profit to deal with urgent social issues resolved. According to Narangajavana (2016: 5) there are two groups that have different perspectives in formulating the definition of social entrepreneurship. First, groups that view social entrepreneurship from the perspective of individuals as business actors. The entrepreneurcentric perspective describes social entrepreneurs as individuals with innovative solutions to the most pressing social problems of society or as 'agents of community change: pioneers of innovation that benefit humanity'. Second, groups that look at process-based social entrepreneurship, which include the introduction of opportunities, defining missions that are achieved through innovative solutions with mobilization of resources owned and then responsibly to constituents. 
Social entrepreneurship is a hybrid of two types of institutions; charity as well as profit institution but not for itself or shareholders (Murphy, J.P., and Coombes, J.S., 2009: 329). EMES researchers (The Emergence of Social Enterprise in Europe) formulate five basic elements which are included in terms of social value (Spear and Bidet, 2003: 9), namely: (1) Activities carried out on collective group dynamics initiatives in the community; (2) Decision making is not based on capital ownership (shares) in an institution; (3) Natural participation occurs because of involvement in joint ventures carried out; (4) Profits obtained are not shared as a whole but limited profit sharing; (5) Having explicit goals, namely for mutual benefit (community).

The decision of a person or group of people in pioneering social entrepreneurship is related to the motivation that drives it. Motivation in social entrepreneurship is described as the greatest motivation for someone to play an active role because the emotion of pro-social alignments manifested in compassion results in sensitivity to pain and creates the desire to eliminate the suffering (Miller, 2012).

Lönnström (2015: 64) divides intrinsic and exintric motivation. Extrinsic motivation is the encouragement of someone to do something because of a 'reward' from the party outside themselves. Encouragement from within is influenced by values that are lived by someone. This value is a guide in recognizing and pursuing opportunities that are not only economically oriented or useful only for entrepreneurs, but also benefit others. Values are also seen as the basis of selfconcept and identity and are related to self-esteem, renewal spirit, self-integrity, meaning in life influencing the quest for mission, wealth or welfare means achieving mission, and humanity and caring for the environment as a reason for a defined social mission (Lönnström, 2015).

According to Omoree, the decision of someone to start social entrepreneurship is one of them due to the encouragement of social problems in the local area, in addition to one's perspective and support of social networks (Omorede, 2014). The impetus is influenced by several factors: (a) Local Condition/Local Condition where the occurrence of social problems (high poverty rate, low education level and 'unscientific' perspective, inequality); (b) Intentional Mindset which includes social sensitivity, religious views, tendency to act and views on morality; (c) Passion for a Cause and (d) Social Network Support, both physical support and emotional support.
In addition to motivation, an important factor in pioneering social entrepreneurship decisions is social networks (Webster and Ruskin, in Seymour; 2012, Sangmi Cho and Ahraemi Kim 2017), and leadership factors (Dees; 2001, Suresh; 2016). According to Northouse (2013: 5) leadership is individual behavior affecting a group of people to achieve a common goal. Leadership according to Sharma and Shilpa Jain (2013: $310)$ is a process in which someone influences others to achieve goals and direct the organization in a way that makes it more cohesive and coherent.

Social entrepreneurship leadership is the agent of a change (Dees, 2001) by creating social value in answering social problems through innovation that results in benefits to support the sustainability of its social mission. The creation of social value is the main goal of social entrepreneurship and not the benefit of a group of people (Santos, 2010), people who are unhappy with the status quo and feel the need to make changes (Castro-Salazar, 2015) because they aim at creating social values, Wronka-social entrepreneurship leadership Pośpiech (2016: 11) is closer to the participatory (integrative) style.

Social networks are social structures that are built by individuals or organizations that are connected by means of exchanging information (Praszkier and Nowak, 2012), or a series of relationships between actors that have the opportunity to realize the creation and transfer of needed resources such as human resources, finance, knowledge, equipment, suggestions /ideas, etc. (Weber and Kratzer, 2013).

The existence of social networks has a strategic role in social entrepreneurship compared to business (traditional) entrepreneurship. First, Social entrepreneurship cannot always demand the fulfillment of all the costs of their products and/or services from their donors. Therefore, this social network is expected to be able to build independence. Second, social networking is a medium to convince volunteers, employees, and investors to be involved in achieving their mission and part of efforts to build bonds and commitments between them.

Social networks are a fundamental need for the development of social entrepreneurship in order to gain access to knowledge and resources, opportunities for collaboration, get issues of building trust, power and choices/alternatives. The overall benefits are contained in the relations system (Webster and Ruskin in Seymour, 2012). Social networking has two basic elements: actors and relations (relationships), the first 
element, actors are actors of social networks that make connections.

This study tested two hypotheses, first $\left(\mathrm{H}_{1}\right)$ : Allegedly Motivation, Leadership and Social Networks had a significant effect on Social Entrepreneurship; second $\left(\mathrm{H}_{2}\right)$ : Allegedly dominant influence on Social Entrepreneurship.

\section{Methods}

This study uses quantitative methods to prove the influence of independent variables Motivation (X1), Leadership (X2) and Social Networks (X3) on the pioneering of Social Entrepreneurship (Y) (as nonindependent variables) in Sumber Makmur I Farmers Group, Sumber Ngepoh Village Lawang District, Malang Regency, East Java, Indonesia. Data was taken by census of farmer group members as respondents using questionnaires based on Likert scale.

The population of this study was members of Sumber Makmur I Farmers Group in Sumberngepoh village, Lawang, Malang regency, East Java with 40 members. Data obtained from questionnaire distribution with three variables, four indicators with 56 questions were processed using the SPSS 16.0 statistical program.

Testing the research instrument using the validity test and reliability test. Testing the validity technique uses the product moment correlation technique from Pearson with a significance level of $5 \%$. If the Pearson correlation total value is $>0.3$, or the probability is less than 0.05 then the item is valid (Arikunto, 2002: 146).

The product correlation formula is:

$$
r_{x y}=\frac{n \sum X Y-\left(\sum X\right)\left(\sum Y\right)}{\sqrt{\left\{n \sum X^{2}-\left(\sum X^{2}\right)\right\} \sqrt{\left\{n \sum Y^{2}-\left(\sum Y\right)^{2}\right\}}}}
$$

Reliability testing of research instruments using formulas (Arikunto, 2009: 193):

$$
\alpha=\left(\frac{k}{k-1}\right)\left(1-\frac{\sum r b^{2}}{a^{2} t}\right)
$$

Data analysis techniques used descriptive analysis and multiple linear regression. Before testing the hypothesis a classical assumption test was carried out consisting of heteroscedasticity, multicollinearity and normality tests. Hypothesis testing uses the F test model (simultaneous test, Ftest) and $\mathrm{T}_{\text {test }}$ model (partial test, Ttest).

$$
F=\frac{R^{2} / k}{\left(1-R^{2}\right) /(n-k-1)}
$$

\section{Results and Discussion}

Results

The validity test in this study is based on product moment $(r)$ at a significant level of 95\% ( $\alpha$ : 0.05). This test of validity correlates the scores of each indicator with the total score of the test as its validation criteria. The following are the results of data processing with the SPSS version 16.0 for Windows program.

Table 1. Results of Validity of Motivation Variable Questionnaire (X1)

\begin{tabular}{cccc}
\hline Item & $\begin{array}{c}\text { Correlation } \\
\text { coefficient } \\
\left(\mathrm{r}_{\text {count }}\right)\end{array}$ & Sig. & Description \\
\hline 1 & 0,651 & 0,000 & Valid \\
\hline 2 & 0,640 & 0,000 & Valid \\
\hline 3 & 0,680 & 0,000 & Valid \\
\hline 4 & 0,567 & 0,000 & Valid \\
\hline 5 & 0,588 & 0,000 & Valid \\
\hline 6 & 0,614 & 0,000 & Valid \\
\hline 7 & 0,552 & 0,000 & Valid \\
\hline 8 & 0,845 & 0,000 & Valid \\
\hline 9 & 0,877 & 0,000 & Valid \\
\hline 10 & 0,878 & 0,000 & Valid \\
\hline 11 & 0,771 & 0,000 & Valid \\
\hline 12 & 0,621 & 0,000 & Valid \\
\hline 13 & 0,355 & 0,000 & Valid \\
\hline 14 & 0,422 & 0,000 & Valid \\
\hline 15 & 0,459 & 0,000 & Valid \\
\hline
\end{tabular}

Source: Primary Data Processed, 2018.

The results of the validity test of the Motivation variable questionnaire (X1) show a sig $(0,000)$ value of less than 0.05 . This shows that four (4) indicators with 15 items of statements in the motivation variable questionnaire (X1) are valid so that they can be used to measure the variables to be measured (attachment I: primary data processed).

Table 2. Results of Validity of Leadership Variable Questionnaire (X2)

\begin{tabular}{cccc}
\hline Item & $\begin{array}{c}\text { Correlation } \\
\text { coefficient } \\
\left(\mathrm{r}_{\text {count }}\right)\end{array}$ & Sig. & Description \\
\hline 1 & 0,812 & 0,000 & Valid \\
\hline 2 & 0,816 & 0,000 & Valid \\
\hline 3 & 0,826 & 0,000 & Valid \\
\hline 4 & 0,787 & 0,000 & Valid \\
\hline 5 & 0,856 & 0,000 & Valid \\
\hline 6 & 0,856 & 0,000 & Valid \\
\hline 7 & 0,871 & 0,000 & Valid \\
\hline 8 & 0,748 & 0,000 & Valid \\
\hline 9 & 0,795 & 0,000 & Valid
\end{tabular}

The results of the questionnaire variable Leadership validity (X2) indicate that three (3) indicators with nine (9) item statements in the leadership variable questionnaire (X2) are valid so that they can be used to 
measure the variables to be measured (attachment: II primary data processed).

Table 3. Results of Validity of the Social Network Variable Questionnaire (X3)

\begin{tabular}{cccc}
\hline Item & $\begin{array}{c}\text { Correlation } \\
\text { coefficient } \\
\left(\mathrm{r}_{\text {count }}\right)\end{array}$ & Sig. & Description \\
\hline 1 & 0,765 & 0,000 & Valid \\
\hline 2 & 0,855 & 0,000 & Valid \\
\hline 3 & 0,779 & 0,000 & Valid \\
\hline 4 & 0,868 & 0,000 & Valid \\
\hline 5 & 0,637 & 0,000 & Valid \\
\hline 6 & 0,859 & 0,000 & Valid \\
\hline 7 & 0,838 & 0,000 & Valid \\
\hline 8 & 0,791 & 0,000 & Valid \\
\hline 9 & 0,844 & 0,000 & Valid \\
\hline
\end{tabular}

Source: Primary Data Processed, 2018.

Test results validity of the sig $(0,000)$ value is less than 0.05 . This shows that two (2) indicators with nine (9) item statements in the social network variable questionnaire (X3) are valid. The results of data processing of seven (7) dependent variable indicators of Social Entrepreneurship $(\mathrm{Y})$ consisting of 24 statement items are sig $(0,000)$ less than 0.05 . This shows that the questionnaire of social entrepreneurship variable $(\mathrm{Y})$ is valid and can be used for variable measurement.

Table 4. Results of Validity of the Social Entrepreneurship Variable Questionnaire (Y)

\begin{tabular}{|c|c|c|c|}
\hline Item & $\begin{array}{c}\text { Correlation } \\
\text { coefficient } \\
\text { (rcount) }\end{array}$ & Sig. & Description \\
\hline 1 & 0,656 & 0,000 & Valid \\
\hline 2 & 0,638 & 0,000 & Valid \\
\hline 3 & 0,881 & 0,000 & Valid \\
\hline 4 & 0,463 & 0,000 & Valid \\
\hline 5 & 0,361 & 0,000 & Valid \\
\hline 6 & 0,709 & 0,000 & Valid \\
\hline 7 & 0,750 & 0,000 & Valid \\
\hline 8 & 0,614 & 0,000 & Valid \\
\hline 9 & 0,715 & 0,000 & Valid \\
\hline 10 & 0,871 & 0,000 & Valid \\
\hline 11 & 0,759 & 0,000 & Valid \\
\hline 12 & 0,795 & 0,000 & Valid \\
\hline 13 & 0,572 & 0,000 & Valid \\
\hline 14 & 0,718 & 0,000 & Valid \\
\hline 15 & 0,537 & 0,000 & Valid \\
\hline 16 & 0,557 & 0,000 & Valid \\
\hline 17 & 0,782 & 0,000 & Valid \\
\hline 18 & 0,655 & 0,000 & Valid \\
\hline 19 & 0,726 & 0,000 & Valid \\
\hline 20 & 0,841 & 0,000 & Valid \\
\hline 21 & 0,787 & 0,000 & Valid \\
\hline 22 & 0,832 & 0,000 & Valid \\
\hline 23 & 0,807 & 0,000 & Valid \\
\hline 24 & 0,741 & 0,000 & Valid \\
\hline
\end{tabular}

Source: Primary Data Processed, 2018.

Instrumental reliability test results in this study. Reliability test results indicate that each value of the reliability coefficient is greater than 0.60 , so the instrument used to retrieve data is declared reliable (reliable).

Table 5. The Value of the Reliability Coefficients of Each Variable

\begin{tabular}{lcl}
\hline \multicolumn{1}{c}{ Variable } & $\begin{array}{c}\text { Reliability } \\
\text { Coefficient }\end{array}$ & Description \\
\hline Motivation (X1) & 0,938 & Reliable \\
\hline Leadership (X2) & 0,895 & Reliable \\
\hline Social network (X3) & 0,932 & Reliable \\
\hline Social Entrepreneurship (Y) & 0,958 & Reliable \\
\hline Soure: Primary Das
\end{tabular}

Source: Primary Data Processed, 2018

Motivation Variables (X1) as a driver of the establishment of social entrepreneurship in Sumber Makmur I Farmers Group there are four (4) indicators consisting of fifteen item statements with an average indicator value of 4.62. This shows that respondents strongly agree that the activities they have carried out are a form of entity called Social Entrepreneurship. The highest indicator with an average value is the social mission indicator (Y1) with a mean value of 4.73 and the lowest indicator is real involvement (Y6) with an average value of 4.56 and open accountability (Y7) with an average value of 4.56 .

The results of heteroscedasticity test (Figure 1) the distribution of points above or below the number 0 on the $y$ axis. This means that there is no heteroscedasticity in the regression model.

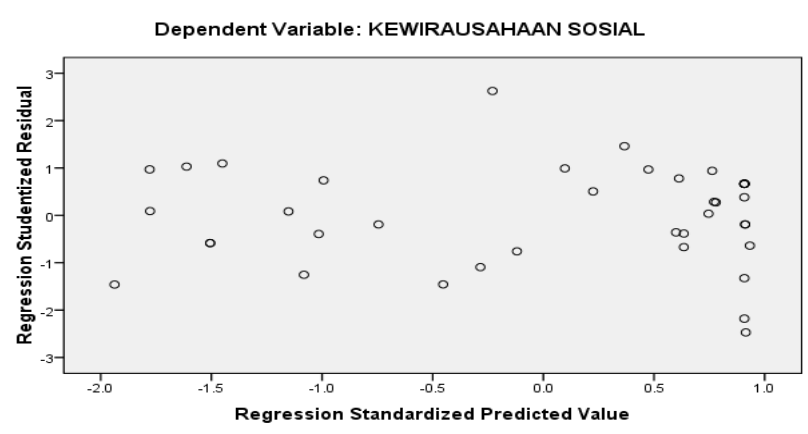

Figure 1. Heteroscedasticity Test Graph Source: Primary Data Processed, 2018.

The detection of multicollinearity can be done by looking at the value of the Variance Inflation Factor (VIF) from the results of the regression analysis. If the VIF value is greater than 5 , there are symptoms of multicollinearity. The results of the multicollinearity test are presented in table 6 .

Table 6. Multicollinearity Test Results

\begin{tabular}{lcc}
\hline \multicolumn{1}{c}{ Model } & \multicolumn{2}{c}{ Collinearity Statistics } \\
\hline & Tolerance & VIF \\
\hline Motivation (X1) & 0,607 & 1.646 \\
\hline Leadership (X2) & 0,293 & 3.408 \\
\hline Social network (X3) & 0,320 & 3.121 \\
\hline
\end{tabular}

Source: Primary Data Processed, 2018. 
Based on the VIF calculation results it appears that the motivation, leadership and social network variables have a VIF value $<5$. This means that it can be concluded that the regression model does not have a multicollinearity problem.

The test results shown in Figure 2 show that the data collected (in the graph appears as a point) is spread out and lined up following the diagonal line. This shows that the data obtained in the study with motivation, leadership and social networks variables are normally distributed.

\section{Dependent Variable: KEWIRAUSAHAAN SOSIAL}

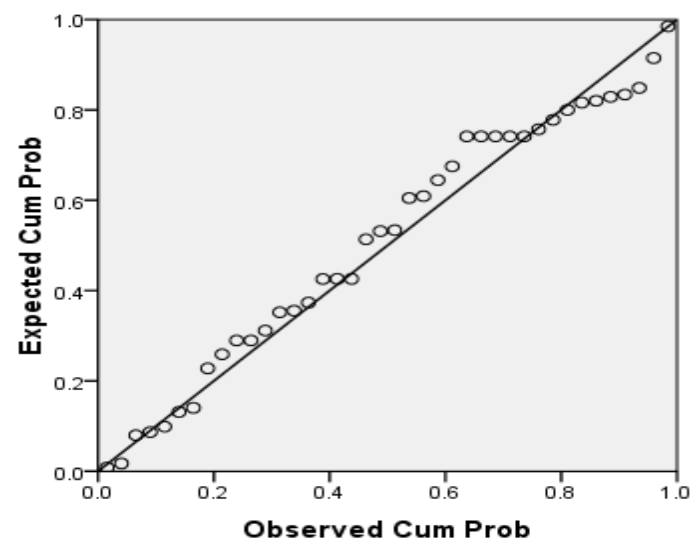

Figure 2. Normality Test Graph

Source: Primary Data Processed, 2018.

Regression analysis is used to determine the level of influence between the independent variables Motivation (X1), Leadership (X2) and Social Network (X3) on Social Entrepreneurship (Y) as the dependent variable. Regression equation is used to determine the shape of the relationship between independent variables and dependent variables. With the help of SPSS for Windows ver 16.0 a regression model is obtained as in table 7.

Table 7. Regression Equations

\begin{tabular}{|l|c|c|c|c|}
\hline \multicolumn{1}{|c|}{ Variable } & $\begin{array}{c}\text { Regression } \\
\text { Coefficient }\end{array}$ & $\mathrm{t}_{\text {count }}$ & Sig. & Description \\
\hline Motivation (X1) & $-0,008$ & $-0,048$ & 0,962 & Not Significant \\
\hline Leadership (X2) & 0,789 & 2,628 & 0,013 & Significant \\
\hline $\begin{array}{c}\text { Social network } \\
\text { (X3) }\end{array}$ & 0,660 & 2,220 & 0,033 & Significant \\
\hline Constanta & \multicolumn{4}{|c|}{23,032} \\
\hline $\mathrm{R}$ & \multicolumn{5}{|c|}{0,812} \\
\hline Adjusted R Square & 0,630 \\
\hline $\mathrm{F}_{\text {count }}$ & \multicolumn{4}{|c|}{0,000} \\
\hline Sig. F & \multicolumn{4}{|c|}{40} \\
\hline $\mathrm{n}$ & \multicolumn{4}{|c|}{ Social Entrepreneurship } \\
\hline Dependent variable $=$ &
\end{tabular}

Source: Primary Data Processed, 2018.

Based on Table 18 an equation will be obtained:

$Y=\alpha+\beta_{1} X_{1}+\beta_{2} X_{2}+\beta_{3} X_{3}+\varepsilon$

$\mathrm{Y}=23,032+\left(-0,008 \mathrm{X}_{1}\right)+0,789 \mathrm{X}_{2}+0,660 \mathrm{X}_{3}$
The above equation can be interpreted: $\mathrm{a}=23,032$ is a constant. This means that if the independent variable Motivation (X1) Leadership (X2) and Social Network (X3) is 0 , then the size of the Social Entrepreneurship variable $(\mathrm{Y})$ is 23,032 .

The magnitude of the regression coefficient of Motivation variable $(\mathrm{X} 1)=-0.048$. If the multiple regression coefficient is negative and a significant value $(0.962)$ is greater than 0.05 , then the motivation variable does not show a significant effect on Social Entrepreneurship.

The amount of the regression coefficient of variable X2 (Leadership) is 2,628. This means that Leadership influences the formation of social entrepreneurship, assuming the motivation variable and social network remain large.

The size of the regression coefficient for social network variable $(\mathrm{X} 3)$ is 2,220. This means that the Social Network that is owned influences the formation of social entrepreneurship, assuming that the motivation and leadership variables remain large.

The correlation coefficient indicates the magnitude of the relationship between the independent variables namely Motivation (X1), Leadership (X2), and Social Networking (X3) with the dependent variable on Social Entrepreneurship (Y). The results of the analysis show the value of $\mathrm{R}$ (correlation coefficient) of 0.812 . This shows that the relationship between the independent variables namely Motivation, Leadership, and Social Networks with Social Entrepreneurship is included in the strong category because it is at the interval of $0.6-0.8$.

From the analysis in Table 6, the results of the adjusted $\mathrm{R}$ (coefficient of determination) are 0.630 . The result means that $63 \%$ of Social Entrepreneurship variables will be influenced by the independent variables, namely Motivation (X1), Leadership (X2), and Social Networking (X3). While the remaining 37\% of Social Entrepreneurship (Y) variables will be influenced by other variables not discussed in this study.

Testing the first hypothesis which states that motivation, leadership and social networks have a significant effect on social entrepreneurship in the Sumber Makmur I Farmer Community in Lawang, Malang. If the test results are significant, then $\mathrm{H}_{0}$ is rejected and $\mathrm{Ha}$ is accepted, whereas if the result is not significant, then $\mathrm{H}_{0}$ is accepted and $\mathrm{Ha}$ is rejected. $\mathrm{H}_{0}$ is rejected if $\mathrm{F}$ count $>\mathrm{F}_{\text {table }} ; \mathrm{H}_{0}$ is accepted if $\mathrm{F}$ count $<$ $\mathrm{F}_{\text {table }}$. The results of the calculation of multiple regression analysis with SPSS obtained Fcount of 
23,171 while $F_{\text {table }}$ at $\alpha=5 \%$ was 2.87 . This means $F_{\text {count }}$ $>\mathrm{F}_{\text {table }}(23.181>2.87)$ while the probability value is smaller than $\alpha=0.05(0.00<0.05)$, then $\mathrm{H}_{0}$ is rejected and $\mathrm{Ha}$ is accepted. This means that the independent variables of motivation, leadership and social networks have a significant effect on social entrepreneurship.

The statement of the second hypothesis is that motivation has a significant influence on social entrepreneurship in the Sumber Makmur I Farmer Group in Lawang District, Malang Regency. This second hypothesis is tested by the $T_{\text {test }}$ which is whether each independent variable (motivation, leadership and social entrepreneurship) has a significant partial effect.

Table 8. Comparison of $\mathrm{T}_{\text {count }}$ with $\mathrm{T}_{\text {table }} \alpha=5 \%$

\begin{tabular}{lcccc}
\hline \multicolumn{1}{c}{ Variable } & $\mathrm{T}_{\text {count }}$ & $\mathrm{t}_{\text {table }}$ & Sig. & Description \\
\hline Motivation (X1) & $-0,048$ & 1,688 & 0,962 & Not Significant \\
\hline Leadership (X2) & 2,628 & 1,688 & 0,013 & Significant \\
\hline Social network (X3) & 2,220 & 1,688 & 0,033 & Significant \\
\hline
\end{tabular}

Source: Primary Data Processed, 2018.

The results of the regression analysis prove the value of $\mathrm{t}$ count $=-0.048$ while the value of $\mathrm{t}_{\text {table }}=1.688$; so that tcount $<\mathrm{t}_{\text {table }} ;-0.048<1.688$ or a significance value of $0.962>0.05$ so that $H_{o}$ is accepted or $H_{a}$ is rejected, and proven Motivation variable $\left(X_{1}\right)$ does not significantly influence Social Entrepreneurship (Y).

From the results of the regression analysis obtained the value of $t_{\text {count }}=2.628$ while the value of $t_{\text {table }}=1.688$; so $t_{\text {count }}>t_{\text {table }} ; 2,628>1,688$ or a significance value of $0.013<0.05$ so $\mathrm{H}_{\mathrm{o}}$ is rejected or $\mathrm{H}_{\mathrm{a}}$ is accepted, and tested Leadership variables $\left(\mathrm{X}_{2}\right)$ have a significant effect on Social Entrepreneurship (Y).

From the results of the regression analysis obtained a value of tcount $=2.220$ while the value of $\mathrm{t}$ table $=$ 1.688; so $t_{\text {count }}>t_{\text {table }} ; 2,220>1,688$ or a significance value of $0.033<0.05$, so that $\mathrm{H}_{\mathrm{o}}$ is rejected or $\mathrm{H}_{\mathrm{a}}$ is accepted, and tested the Social Network variable $\left(\mathrm{X}_{3}\right)$ has a significant effect on Social Entrepreneurship (Y).

Based on the results of the $t$ test above, it can be proven that the motivation variable does not significantly influence social entrepreneurship. Leadership variables and social networks partially have a significant influence on social entrepreneurship.

The independent variable which has a dominant influence can be seen from the magnitude of the regression coefficient which has a significant effect on social entrepreneurship. Based on the results of multiple regression analysis it can be stated that the largest independent variable which has the dominant influence is the leadership variable with a regression coefficient of 0.789 . This value is greater than the value of the free social network variable which is 0.660 . Thus according to the regression coefficient analysis the variable that has the dominant effect is the leadership variable $\left(X_{2}\right)$, so the second hypothesis which states that the motivation variable $\left(\mathrm{X}_{1}\right)$ has a significant influence on social entrepreneurship, is statistically rejected because the motivation effect is not significant.

\section{Discussion}

The results of the analysis of the average value proved the respondents stated strongly agree that each of the independent motivation variables $\left(X_{1}\right)$, leadership $\left(X_{2}\right)$ and social networks $\left(X_{3}\right)$ has a significant effect on social entrepreneurship $(Y)$.

The economic crisis experienced by the Indonesian people in 1997-1998 resulted in social problems, especially farmers in Sumber Ngepoh, Lawang, Kab. Poor. These social problems include rising prices for fertilizers and insect / pest spray poisons. This triggers deeper problems, namely the dependence of farmers on the availability of factory fertilizers on the market and erodes the skills of farmers in making fertilizers and poisons, as well as environmental damage due to the use of fertilizers and insect killer poisons.

According to Omorede (2014: 242) someone pioneering and surviving/persevering in social entrepreneurship is driven by the desire to create social impacts in finding solutions to complex social problems. The social problems experienced by farmers can be mentioned as an external driving factor. According to Lönnström (2015: 29) the motivation that drives social entrepreneurship is intrinsic and extrinsic factors. Intrinsic motivation is a tendency from within that is influenced by values that are lived or held by the actors of social entrepreneurship. The values that motivate social entrepreneurship include background experience in the past as a reason for establishing social entrepreneurship, renewal spirit determines which mission will be achieved, selfintegrity influences social entrepreneurs operating their business, meaning in life influences the quest for mission, wealth or welfare means achieving mission and humanity and environmental care as reasons for the defined social mission (Lönnström (2015: 64).

The results of the analysis of the simultaneous influence of respondents state that leadership variables and social networks have a significant effect and the motivation variable has no significant effect. The leadership variable is the most dominant variable influential. 
The decision of the five people indicated that they were ready to take the risk of the uncertainty of implementing organic farming. It takes at least three years to restore the quality of soil fertility. During the transition period their yields decreased in number. They learn by digging back the old knowledge that has been done by the predecessors who plant organically who need organic ingredients that they have to work on. When the harvest season arrives with decreasing numbers due to changes in planting methods, the price of their harvest also cannot be called organic rice. As a result, the selling price follows the price of conventional grain or rice. They faced various difficulties together.

The pattern is in accordance with the characteristics of social entrepreneurship leadership according to CastroSalazar (2015: 9-14) that innovation, creativity and flexibility are strategic elements in finding solutions to problems. According to Castro-Salazar, a social entrepreneur who explores and is open to new ideas and does a combination of different things done consistently (2015: 10).

In this study, the points of innovation, creativity and flexibility as well as courage in exploring new things proved to have the highest coefficient value from yakti respondents of 4.70. Another leadership element that supports creativity so that it gives birth to innovation is the ability to collaborate (collaboration) by involving the participation of many parties and the inclusiveness (openness) to enable mutual influence. According to Castro-Salazar there is no effective way to influence one another and collaborate without education (2015: 10). This study proves that the element of leadership collaborating, participation and inclusiveness is the second indicator of leadership variables with the second highest coefficient value of respondent of 4.66. The elements of learning and learning spirit are carried out continuously as an indicator of the third leadership, getting coefficient value from the respondents of 4.53.

Armed with the values believed by pioneer farmers who viewed organic farming as having many positive things, they explored "unwritten knowledge" (tacit knowledge) that had been applied by the predecessors as part of the local wisdom that had been inherited. The dynamics of this experience become the driving motivation for social change (Prabhu, 199: 143, Omorede, 2014: 242). The five farmers were able to survive in the transition period and had an impact on other farmers following the decisions taken. People like that according to Luthans in accordance with the Great Man Theory formula that is someone who is born with certain characteristics that support him to survive from any situation in a period of history he will become a leader (2006: 641).

Leadership is the dominant variable that has an influence with a regression coefficient of 0.789 . This value is greater than the value of the free social network variable $(0.660)$. This leadership becomes a strategic element because in addition to its ability to identify problems that occur, read opportunities, recognize their potential and know the limitations of existing resources. Resource mobilization is needed when efforts to achieve predetermined goals, both resources from within and from outside the community/social group. In this context the strategic role of leadership is primarily concerned with mobilizing existing resources outside the group/ community by building social networks that are able to support the achievement of stated objectives According to Webster and Ruskin (Syemour, 2012: 150) through social entrepreneurship networks gain access to knowledge and resources, opportunities for collaboration, getting issues to build trust, power and choice/alternatives. The overall benefits are contained in the relations system.

The applied leadership pattern is a transformational leader model that has charisma that influences its followers. Charismatic leaders are leaders who are able to generate strong emotions and are made as role models for their subordinates to be trusted, respected, and have a vision and mission that their subordinates perceive to be realized (Bass, 1985). With the strength and influence they have, leaders easily direct their subordinates to devote all their energy and thoughts to the interests of the organization.

Sumber Makmur I Farmers Group built cooperation with various parties to strengthen their social networks including educational institutions (both with Vocational Schools and some Universities), government institutions (Malang District Agricultural Service), business institutions and other social groups or communities. The relationship system is built on a mutually beneficial and fair value system which is part of achieving the mission of creating social value as the goal of social entrepreneurship.

The social values include: striving for independence in the provision of organic anti-pest fertilizers and drugs, independence in determining selling prices, nature conservation efforts because they are related to the availability of springs, cooperation in the oganik rice production process. Included in this case is the increase in welfare level from increasing yields received by farmers. The achievement of these social values gets the 
highest response in the Social Entrepreneurship indicator with an average value is the social mission indicator (Y1) with a mean value of 4.73 .

Thus the performance of Sumber Makmur I Farmers Group in Lawang, Malang Regency, has answered the needs of goods or services that cannot be accessed by a community group because of its limitations by making it an opportunity to increase social wealth in innovative ways (Zahra, 2009: 522) to achieve change social (Dees, 1998: 4, Singh (2016: 30). All efforts to create social values are generated from collaboration with people/communities and organizations from civil society involved in social innovations applied in economic activities (Hulgard, 2010: 4, Austin, 2006: 371, Nicholls (2006: 13).

This study still needs to be developed further because it only looks at the influence of three factors (motivation, leadership and social networks), there are still other factors that have influence in shaping social entrepreneurship.

\section{Conclusion}

Based on the results and discussion of the purpose of this study it can be concluded that the results showed that motivation, leadership and social networks had influence on the efforts of pioneering social entrepreneurship conducted by the Sumber Makmur I Farmers Community. The leadership variable was the dominant variable.

\section{References}

Austin, J., Stevenson, H., Wei-Skillern, J., 2006, Social and commercial entrepreneurship: same, different, or both? Entrepreneurship: Theory and Pratice Journal, da Baylor University, Estados Unidos, volume 30, número 1, páginas 1-22, Janeiro de.

Banks, J. (1972). The Sociology of Social Movements, Macmillan, London, 53.

Bass, B. M. (1985). Leadership and performance beyond expectation. New York, NY: The Free Press.

Barringer, R., Bruce., and, Ireland, Duane, R. (2013). Entrepreneurship: Successfully Launching New Venture, Fourth Edition, Pearson Educatoin Limited, Eidenburg Gate, England.

Bornstein, D., Davis, S. (2010). Social Entrepreneurship What Everyone to Know, Oxford University Press, Inc., New York.

Castro-Salazar, R. (2015) "The many faces of social entrepreneurial leadership" In Collective Efficacy:
Interdisciplinary Perspectives on International Leadership, Emerald Insight, 3-21.

Cho, S., \& Kim, A., 2017, Relationships Between Entrepreneurship, Community Networking, and Economic and Social Performance in Social Enterprises: Evidence from South Korea, Human Service Organizations: Management, Leadership \& Governance Journal, Volume 41, Issue 4, 376-388.

Dees, Gregory, J. (2001). The Meaning of "Social Entrepreneurship.

https://entrepreneurship.duke.edu/news-item/themeaning-of-social-entrepreneurship/. Diakses pada 2 Maret 2018, pukul 14.58.

Drucker, F., Peter. (1985). Innovation And Entrepreneurship Practice and Principles, New York Harper Business.

Hamilton, R.T., and, Harper, D.A. (1994). The Entrepreneur in Theory and Practice, Journal of Economic Studies, MCB University Press, Vol. 21 No. 6, pp. 3-18.

Harahap, Romida, Siti. (2013). Deteksi Dini Krisis Nilai Tukar Indonesia: Identifikasi Periode Krisis Tahun 1995-2011, Economics Development Analysis Journal, Vol. 2, No. 4.

Diakses pada 28 Januari 2019, https://journal.unnes.ac.id/sju/index.php/edaj/issue/ view/366

Hebert, F., Robert, and, N., Albert. (2006). Historical Perspectives on the Entrepreneur Foundations and Trends in Entrepreneurship, Vol. 2, No 4, 261-408.

Hulgård, L. (2010). Discourses of social entrepreneurship variations of the same theme? EMES European Research Network.

Light, P.C. (2006). Reshaping Social Entrepreneurship, Stanford Social Innovation Review, Copyright by Leland Stanford Jr. University All Rights Reserved.

Lönnström, A., et.al. (2014). Social Entrepreneurship, Leveraging Economic, Political, and Cultural Dimensions, Springer International Publishing Switzerland.

Mair, J., Noboa, E. (2003). Social Entrepreneurship: How Intentions To Create A Social Enterprise Get Formed, IESE Business School - Universidad de Navarra.

Miller, T. 1., Grimes, Matthew., Mcmullen, Js., Vogus, Tj. (2012). Venturing For Others With Heart And Head: How Compassion Encourages Social Entrepreneurship, Academy of Management Review, Vol. 37, No. 4, 616-640. 
Murphy, J.P., Coombes, S.M. (2009). A Model of Social Entrepreneurial Discovery, Journal of Business Ethics, Springer.

Narangajavana, Y., Gonzalez-Cruz, T., GarrigosSimon, F., and Cruz-Ros, S. (2016). Measuring social entrepreneurship and social value with leakage. Definition, analysis and policies for the hospitality industry, Springer Science Business Media, New York.

Nicholls, A, et.al. (2006). Social Entrepreneurship New Models of Sustainable Social Change, Oxford University Press Inc., New York, United States.

Northouse, Peter Guy. (2013). Leadership : theory and practice, 6th ed., SAGE Publications, Inc, Western Michigan Univerfsity, United States.

Omorede, A. (2014). Exploration of motivational drivers towards social entrepreneurship, Social Enterprise Journal, Vol. 10 Iss 3 pp. 239 - 267.

Praszkier, Ryszard, and, Nowak, Andrzej. (2012) Social Entrepreneurship theory and practice, Cambridge University Press, 32 Avenue of the Americas, New York.

Santos, Filipe M. (2009). A positive theory of social entrepreneurship, 15 February, INSEAD, Working Paper /23/EFE/INSEAD. Retrieved May 29, 2013, fromhttp://ssrn.com/abstract=1553072.

Schumpeter, Joseph, Alois, (1934). 1883-1950, The theory of economic development, Social science classis series, Translation of: Theorie der wirtschaftlichen Entwicklung, Reprint. Originally published: Cambridge, Mass.: Harvard University.

Sharma, Kumar, Manoj, and Jain, Shilpa. (2013). Leadership Management: Principles, Models and Theories, Global Journal of Management and Business Studies, ISSN 2248-9878 Volume 3, Number 3, pp. 309-318 (C) Research India Publications.

Singh, Archana. (2016). The Process of Social Value Creation A Multiple-Case Study on Social Entrepreneurship in India, Springer India, 3.

Spear, R. and Bidet, E. (2003). The Role of Social Enterprise in European Labour Markets, EMES Working Papers Series, 3/10.

Suresh, M. R. (2016). Leadership in social enterprisedimensions and insights. Contemporary Research in Management - Vol. V. by Mousumi Sengupta and Nilanjan Sengupta [Compilers]. Mysore: Shri Dharmasthala Manjunatheshwara Institute for Management Development (SDMIMD).
Sutanto, R. (2002), Pertanian Organik. Kanisius. Yogyakarta.

Sutrisno, Lukman, 2002, Paradigma Baru Pembangungan Pertanian. Sebuah Tinjauan Sosiologis, Kanisius, Yogyakarta.

Wronka-Pośpiech, M. (2016). The Relationship Between Leadership Style and success in social enterprises - evidence from poland Research on enterprise in modern economy Quarterly Journal - No 3.

Weber, C. and Kratzer, J. (2013). Social entrepreneurship, social networks and social value creation: A Quantitative analysis among social entrepreneurs', Int. J. Entrepreneurial Venturing, Vol. 5, No. 3, pp.217-239.

Webster and Ruskin dalam Syemour, R.G. (2012). Handbook of Research Methods On Social Entrepreneurship; Socil Network Analysis, Edward Elgar Publishing Limited, The Lypiatts, 15 Lansdown Road, Cheltenham, Glos GL50, 2JA, UK, 150.

Weerawardena, Jay., Gillian Sullivan Mort. (2006). Investigating social entrepreneurship: A multidimensional model, Journal of World Business 41 (2006) 21-35.

Zimmere, Thomas W., Scarborough, Norman, M, Wilson, Doug. (2008). Essentials of Entrepreneurship and Small Business Management, $5^{\text {th }}$ ed., Salemba Empat, Jakarta, 4.

Zahra, S. A., Gedajlovic, E., Neubaum, D. O., \& Shulman, J. M. Forthcoming. (2009). A typology of social entrepreneurs: Motives, search processes and ethical challenges. Journal of Business Venturing. 